\title{
Erratum to: Multiple imputation is better than KDIGO guidelines for estimating unknown baseline renal function
}

Matthieu Jamme* and Guillaume Geri

Unfortunately, the original version of this article [1] was publishing without its corresponding author response and associated references included. This has now been corrected in the original article.

Received: 22 April 2016 Accepted: 22 April 2016

Published online: 17 June 2016

\section{Reference}

1. Jamme M, Geri G. Multiple imputation is better than $\mathrm{KDIGO}$ guidelines for estimating unknown baseline renal function. Critical Care 2016;20(105):1.

\footnotetext{
Submit your next manuscript to BioMed Central and we will help you at every step:

- We accept pre-submission inquiries

- Our selector tool helps you to find the most relevant journal

- We provide round the clock customer support

- Convenient online submission

- Thorough peer review

- Inclusion in PubMed and all major indexing services

- Maximum visibility for your research
}

Submit your manuscript at

www.biomedcentral.com/submit 